\title{
The Responsibility of the Public Official in the Crime of Favoritism (Mediation) and Nepotism in Accordance with the Jordanian Integrity and Anti-Corruption Law
}

\author{
Dr Ibtisam Mousa Saleh, Dr Mo'men Nayef Al-abb`adi \\ Assistant professor -faculty of law, Amman Arab University, Amman - Jordan \\ Ibtisam_saleh@yahoo.com \\ Assistant professor_faculty of law, Amman Arab University, Amman - Jordan
}

\begin{abstract}
The aim of this study was to identify the provisions related to the responsibility of the public official when violating the Integrity and Anti-Corruption Law and committing the crime offavoritism (Mediation) and nepotism, by addressing the substantive provisions for this crime and indicating the general pillars, which are legal, material and moral. In addition to the element required by the legislatorwhich is having aspecific characteristic for the perpetrator, that is being a public official. It also aims to clarify the individuals involved in the crime of nepotism and the extent of the responsibility they holdaccording to the Jordanian legislator and the sanctions determined for the perpetrator. This is done by following the descriptive and analytical approach in investigating the provisions of the Integrity and Anti-Corruption Law No. (13) of 2016. The problem of the study is summarized in the failure of the Jordanian legislation to clarify the concept of the nepotism crime and its pillars, as Article (16 / A / 7) of the Integrity and Anti-Corruption Law merely criminalizes the acceptance of favoritism (Mediation) only. The study resulted in a number of findings and recommendations, the most important of which is amending the text that address this crime to include parties involved in favoritism (Mediation), the one who seeks favoritism (Mediation) and the mediator in the Integrity and AntiCorruption Law, and not only to criminalize the employee who accepts the favoritism (Mediation), as is the case with other crimes. Moreover, to explain the nature of the violation of rights when committing the crime offavoritism(Mediation), because the phrase "Denying justice and revoking a right" in Jordanian legislation is a loose phrase and extends to all rights.
\end{abstract}

Keywords:

favoritism (Mediation) ,nepotism, mediation, corruption, public official, criminal sanction.

Article Received: 18 August 2020, Revised: 3 November 2020, Accepted: 24 November 2020

\section{Introduction}

Financial and administrative corruption in both the public and private sectors represents a danger and a threat to national security. There is a form of corruption, despite its seriousness and spread, has not received much attention which is favoritism (Mediation). It is one of the forms of corruption deeply rooted in the culture of many societies, and it is one of the daily practices to which members of society are accustomed, even though it affects social and moral values.

This crime is one of the most common practices in the daily life of individuals that leads to infringing the rights of others, misappropriating public funds and attacking the values of the society. This would not have occurred had it not been for some influential people seeking to hire employees based on favoritism (Mediation), recommendation, or a request contrary to the general context of administrative work, either for money or prestige at the expense of others.

The Jordanian legislator has criminalized favoritism (Mediation) and nepotism in the Integrity and Anti-Corruption Law No. 13 of 2016. It stipulates in Article (16/ A / 7) that the acceptance of favoritism (Mediation) and nepotism by employees of the General Administration is considered corruption that denies justice and revokes a right. 
4- The definition of favoritism (Mediation) and nepotism?

The crime of favoritism (Mediation) and nepotism is a serious criminal phenomenon threatening the public office, as it is one of the new corruption crimes that the Jordanian legislator has addressed along with its legal provisions to protect the integrity of the public office from being violated. Therefore, it was necessary to start with a clarification of this concept in order to recognize this scourge that threatens our society

4.1 Legislative definition of favoritism (Mediation) and nepotism

The Jordanian legislator did not definefavoritism (Mediation) and nepotism and relied on the opinions of the jurisprudence and court ruling, noting that it is considered in the Integrity and Anti-Corruption Law No. (13) of 2016, as one of the corruption crimes. Moreover, it is within the field of competence of the Integrity and AntiCorruption Commission, as indicated in Article 16 .

The Jordanian legislator did well by not including a definition of this crime in the legislation, leaving it to jurisprudence and court ruling, for fear that a definition might be incomplete (Al-Raqqad and Kasasbeh, 2016, p . 101). The legislator merely clarifies the elements of the crime and the sanctions, but it may sometimes intervene to set a definition of the crime to settle any dispute that may arise during implementation (Al-Raqqad, 2012, p .10)

The second article of the draft United Nations Convention against Corruption of the Year 2003 stipulated in Paragraph (M), that "the term corruption means carrying out acts that represent improper performance of duty, or abuse of a position or authority, including acts of omission in anticipation of a benefit or in pursuit of an advantage that is promised or offered or requested, directly or indirectly, or after accepting a privilege granted directly, either to the same person or for the benefit of another person. This means that the 2003 United Nations Convention against Corruption does not define the crime of favoritism (Mediation).

4.2 Definition offavoritism (Mediation) and nepotism in jurisprudence

Some jurisprudence defines favoritism (Mediation) as "the request made by an individual to a public official to perform a legitimate or unlawful act for his benefit or for the benefit of another individual" (Ayesh, 2000, p: 8). Another aspect of the jurisprudence defined it as "When an employee performs his job as a result of the interference of an influential person with the aim of denying justice and revoking a right "(AlKilani, 2000, p .: 422).

Others defined it as "helping an individual to acquire a right to which he is not entitled or exempting him from obligations he must fulfillwhich harm others." This type of mediation is considered reprehensible. However, there is another type of mediation, that is consideredcommendable mediation, which is to provide assistance to an individual to acquire a right to which he is entitled or exempting him from a condition that he may not meet " (AlJunaidi, 2011, p . 43).

Whereasnepotism was defined by the jurisprudence as "interference in the interest of an individual or group unprofessionally and disregarding the necessary competence, such as appointing a person to a specific position for reasons related to kinship or party affiliation despite being incompetent or ineligible" (Mahdi, 2010, p . 23).

While others defined it as "carrying out actions for the benefit of an individual, group, or party to which the person belongs, such as a party, family, region, or institution, or the act of exchanging goods and services for political support, without being entitled to it" (Omar, 2010, p . 437).

As for mediation, some jurisprudence defined it as "an act carried out by individuals in the interest of the person in need of mediation with the public official" (Al-Jubouri, 2013, p . 299)

Favoritism (Mediation) and mediation should not be confused even though some jurisprudence 
confuses them. Mediation is a legal term, taken from Latin (mediation from mediar) in the sense of intersession. Mediation in the work context refers to the collective dispute resolution procedure at work through the intervention of a mediator who is given broad powers, and whose duty to gather full information about the dispute and proposes a solution in the form of a reasoned recommendation.

As for criminal mediation, some have defined it as: "An alternative judicial system, whereby the Public Prosecution is authorized, with the consent of the two parties, the perpetrator and the victim, to refer the case to a mediator, whether a natural or legal person, to reach a settlement to the conflict, end the social disruption resulting from the crime, compensate the victim, and rehabilitate the perpetrator "(Ashraf, 2012, p. 18).

From the foregoing, we find that favoritism (Mediation) is a form of intervention, request, order, or pleading by an intermediary to the public official to do a job related act for the person concerned. Whereasnepotism is when a public or private official gives priority to relatives, friends and acquaintances in cases of selection, recruitment and career promotion in institutions or in cases of tendering. It is considered one of the most prominent forms of corruption in the worldbecause the prevailing values and culture emphasize the idea of the extended family and the individual's attachment to his family, relatives and friends. Therefore, upon assuming an important position, one is expected to provide his services to those with whom he is related or connected.

\section{The pillars of the crime of} favoritism(Mediation) and nepotism

Crimes in general, provided that a legal text describes it as a crime, consist of two basic pillars, which are the materialand mental. However, in some crimes, the legislator presupposes special elements, so that even if the material and mental elements are available the text cannot be applied except when these elementsare also present. The crime of favoritism (Mediation) and nepotism is one of these crimes that require the presence of special elementsthat are presupposed which is in this casehaving the status of a public official.

\subsection{Legal pillar}

The legal pillar indicates the illegality of the act. The reference in defining it is the provisions of the penal code, and no act is considered a crime except with the presence of this element. (AlMajali, 2015, p. 300). In this sense, a legal principle is established, which is the principle of legitimacy represented by the text of Article (3) of the Jordanian Penal Code, and accordingly acrime does not exist unless it is addressed in a text and penalty is provided only based on textsstatingthe punishable acts. That means that the referenceregarding he illegality of an act is the text of the law, that is called the "criminalization text" and according to the criminal law it includes the penal code, the complementary laws, and the special penal laws. (Al-Jubour, 2012, p . 123)

The legal pillar of the crime of favoritism (Mediation) and nepotismis the text of Article (16 / A / 7) of the Integrity and Anti-Corruption Law No. (13) of 2016 and its amendments, which stipulated that the involvement in favoritism (Mediation) and nepotism thatdenies justice and revokes a rightby public administration employees is considered corruption, provided that thereare no grounds of justification stipulated in Articles (59 to 62) of the Penal Code.

\subsection{Presupposed pillar (perpetrator)}

The crime of favoritism (Mediation) and nepotism, like crimes of public interest, requires a presupposed pillar for its perpetrator, which is to be committed by a public official and those in similar positions. This element raises many problems at the conceptuallevel because the laws did not agree on definition for the public official, as Article 16, paragraph A / 7 of the Integrity Law stipulated that this act should take place by the public administration employees, and the law merely defined public administration in Article 2 as"Ministries, government departments, official public institutions, public institutions and municipalities " 
Thus, it can be said that the Jordanian legislator in the Integrity Law has not set a clear definition of a public official or a public position based on whether the person involvedis an employee or not. Rather, it merely enumerated the bodies subject to regulationwhen a petition is filed against it but without extending the definition to include the concept of the employee with regard to corruption crimes in accordance with Article 11 of the Integrity and Anti-Corruption Law.

As for the Jordanian Penal Code No. (16) of the 1960, the legislator defined the involved employee in the chapter on crimes that occur against the public administration, in Article 169 as follows: "The term employee in this chapter refers to every public employee in the administrative or judicial corps, every officer of the civil or military authority or one of its members, and every worker or employee in the state or in a public administration

Accordingly, the Jordanian legislator in the penal code did not clearly define the concept of the employee, but rather the definition indicated the government departments in which the employee works including the administrative or judicial corps or civil or military authorities.

The Economic Offences Act No. 11 of 1993 defined the employee in Article 2, paragraph A, as: "The word employee with regard to this law includes every official, employee, or worker appointed by the competent authority in any of the bodies stipulated in Paragraph (B) of this Article." These bodies are: ministries, departments, public official institutions, the Senate and the House of Representatives, municipalities, village councils, common services councils, associations, federations, societies, clubs, banks ,public jointstock companies specialized lending institutions, political parties, any party whose budget is provided mainly from the state's budget and whatever body whose funds are considered public according to the law.

The definition of the employee statedin the Economic Crimes Law is connected to the crimes specified in Article 3. An economic crime is any crime to which the provisions of this law apply, which a special law has identified as an economic crime or which harms the economic position of the Kingdom or the public confidence in the national economy, the national currency, stocks, bonds, traded securities, or the public funds. This expanded census does not apply to other crimes, including the crime of favoritism (Mediation) and nepotism, as the concept of economic crime does not encompassesit.

As for the public official concept according to the Jordanian civil service regulationsof 2020 , it is defined as the person appointed by a decision of the competent authority in a post that had been listed in the job description schedule that is issued under the General Budget Law or the budget of one of the departments. The employee is the one appointed under a contract and does not include the person who receives a daily wage. (Article 2, Civil Service Regulations of 2020)

The jurisprudential definitions of the public official have varied, some have defined it as: "Whoever works in a permanent or temporary position in the service of a public utility that is managed by a legal person, or through direct management" (Al-Hafith, 1979, p . 40), while others believe that the public official is "The individual working for a legal person under public law and has a regular status governed by laws and regulations (Al-Tamawi, 1982, p . 399)

From the foregoing, we find that there are differences in legislations with regard to the definition of the public official, which in the crime of favoritism (Mediation) and nepotism does not hold a group of elected groups that are considered similar to public officials accountable such as members and heads of elected municipal councils. They are not considered employees of public administrations even though they are considered among the groups that most likely would practice favoritism (Mediation) and nepotism to ensure they are elected again.

It is worth noting that if an economic crime was committed and the means that facilitated its occurrence was the crime of favoritism 
(Mediation) and nepotism, then the definition of a public official is determined according to the Economic Crimes Law. This is the most viable option because it is more comprehensive and general, and because the Integrity and AntiCorruption Law did not provide a definition for the public official. Therefore, the Jordanian legislator must take into consideration the importance of developing a clear and comprehensive definition of the public official from the criminal point of view to ensure the functioning of the public sector, its good performance and protect it from whims, inclinations and absurdity.

\subsection{Materialpillar}

The material pillar of the crime is based on three elements, the criminal activity, the criminal consequence, and the causal relationship.

\subsubsection{Criminal activity}

The criminal activity according to the text of Article (16 / A / 7) of the Integrity and AntiCorruption Law No. (13) of 2016 and its amendments, refers to the act of being involved in favoritism (Mediation), and that such involvement is serious and explicit through external means that publicly indicated the public official's involvement in the act of favoritism (Mediation) and nepotism. Involvement means a behavior by the one who is addressed for the purpose of meditation which is represented in his response, direction of will and acceptance of the request made by the mediator in favor of the one meditated for. This matter calls for an act of favoritism (Mediation) to be preceded by acceptance and that the acceptance results in denying justice or revoking a right .

The acceptance may be expressed verbally, which is the most spread form.It can be direct face to face or through communication messages. Also, acceptance can take placethrough any mean of writing. It may be explicit or implicit. Therefore, acceptance is an affirmative behavior that requires an organic movement and causes change in the outside world. As for the negative behavior, it has no room in this crime, as abstaining from acceptance means not committing the crime in the first place (Al-Saeed, 2008, p . 449).

The acceptance according to the legal structure of the crime of accepting favoritism (Mediation) in the Jordanian legislation is represented by the will, which must be serious and accurate, meaning that the acceptance is actual. Also, seriousness in the request is required, in addition to the agreementof the mediator and the public official to fulfill a need for the one meditated for. (Raggad, 2012, p .: 89).

The criminal activity takes place by accepting mediation, provided that this acceptance is accompanied by denying justice and revoking a right. Acceptance is based on will, therefore acceptance must be coming from a person who has free will, because this act constitutes an assault on others or on the rights of others, and no action is regarded a crime unless it is committed by a person who has a full and conscious will and who is fully aware of his actions and their consequences.

Therefore, will must not be tainted by any fault identified by the general provisions in the Penal Code. Consequently, if the act was carried out by a person lacking awareness or deprived of will, such as being forced to carry out criminal acts, being forced to carry out an act out of necessity, being insane, young, or incapable of discretion. (Mahdi, 2017, p .: 255).

\subsubsection{The criminal consequence}

The Jordanian legislator has affirmed that criminal behavior according to Article 16 / A / 7 of the Integrity and Anti-Corruption Law is achieved by accepting favoritism (Mediation) and ithas stipulated that such acceptance involves denying justice and revoking a right. The criminal consequence in terms of its material meaning in the crime of favoritism (Mediation) and nepotism is the act of accepting favoritism (Mediation) results in a violation of a right, whether in the form of revoking it or establishing it illegally. However, inlegal terms, criminal consequence is represented by the aggression that the favoritism (Mediation) inflicts on rights in their broad sense 
and that are covered by the penal protection according to the text of the previous article (AlMousawi, 2009, p. 18).

It is notable that the Jordanian legislator was not successful in determining the criminal consequences, as it considers the mere utterance of acceptance to mean that the crime took place because it used the phrase(Denying justice or revoking a right) which are vague terms and need to be interpreted. The basic principle in penal texts is accuracy and specificity so as not to provoke controversy when applied toa dispute before the judge.

The crime of favoritism (Mediation) and nepotism is considered a misdemeanor, and no explicit provision has been made regarding the application of the penalty to the perpetrator in the case of attempt. This is held against our Jordanian legislator because this crime is one of the most difficult crimes to prove and one of the widespread crimes in our society.If the desire of the legislator to fight it and eradicate is unrelenting, it is a priority to criminalize the initiation of it and all corruption crimes as well as to impose the necessary punishment in order to achieve deterrence and protection for society. Thus, whoever attempts to consider such actions would have to stop and reconsider.

5.3.3 Causal Relationship between Action and Effect

With regard to the offense of accepting favoritism (Mediation) and nepotism in Jordanian legislation, the causal relationship is determined if the criminal consequence represented in revoking a right resulted from the acceptance of favoritism (Mediation) and nepotism, meaning that the relationship is proven if denying justice or revoking a right was due to the criminal activity of the perpetrator through his acceptance of favoritism (Mediation) and nepotism. The public official's acceptance of favoritism (Mediation) is considered a criminal behavior due to the consequence of this acceptance.It involves the public official's free will and consent without any external influence to deny justice or revoke a right for the sake of the one mediated fortill the physical element of the crime is achieved and thus criminal responsibility is achieved.

Whereas, if the violation of a right was due to the applicant's circumstances, his job influence, or for any other circumstance, then the official does not hold responsibility in such a case, and this case cannot constitute the legal structure for the crime of accepting favoritism (Mediation) and nepotism (Raggad, 2012, pp: 82-83)

However, if the public official denies justice or revokes a right out of sympathy for the person of interest or on his own without the involvement of (the mediator), he is administratively accountable for his action since the material element has not been achieved, so the violation took place by the public official without any response or acceptance to any mediator.

\subsection{The moral element}

The crime of favoritism (Mediation) and nepotism is one of the intentional crimes that he cannot be commited as a result of negligence, lack of precaution, or violation of regulations, but rather it iscommitted voluntarily knowing well that it is a criminal act and the consequences resulting from it. (Abu Afifa, 2012, p. 201).

The moral element is represented by criminal intent, and this is stated by the Jordanian legislator, in Article 63, which defined it as: "The will to commit a crime as defined by law". According to this text, the basis of the criminal intent is will, but will does not play a role unless it is based on knowledge. Accordingly, intent consists of two elements: will and knowledge. "In the crime of favoritism (Mediation) and nepotism, the legislator did not entail a special intention related to the offense. Rather, the general rules of intent apply to it, which is that the public official has accepted favoritism (Mediation) willingly without any influence, and at the same time he is aware that he is committing an act that violates the law which is achieving the interest of the one meditated for through revoking a right of another. 
Thus, as a reverse result of revoking the right, falsehood takes place ((Al-Saifi, 2001, p .: 162).

The criminal intent may take the form of probabilistic intent, thus it is not required that the result of the act is what the perpetrator wanted, as it is sufficient for the perpetrator to expect its occurrence before proceeding further. For example, manipulatingthe sheets of interview marks to revoke a certain person's right as a result of his acceptance of favoritism (Mediation) while knowing that another person's right may be denied, nevertheless, he carries out his crime and accepts the risk. Thus, his intention is to deny the first's right is direct while the other's is probabilistic.

In the event that the crime of favoritism (Mediation) and nepotism is linked to an economic crime, in which the legislature requires that the perpetrator hasa intent to harm the public economic system and public funds, we consider the necessity of having this intention available to the perpetrator of the crime of favoritism (Mediation) and nepotism. In other words, to be aware that by accepting favoritism (Mediation) and having the will to achieve the result that denies justice or revokes a right, he is committing a crime. Also, to be aware that what his actionswouldcause harm to public funds and the general economic system. In this case the provisions of the Economic Crimes Law can be applied in terms of combining penalties, imposing preventive detention, travel bans, and conducting reconciliations to non-public officials in accordance with Article 9 of the Economic Crimes Law No. 11 of 1993 (Al-Masa'deh, 2005, p. 300)

6. Criminal complicity in the crime of favoritism (Mediation) and nepotism

Criminal complicity is the contribution of more than one person (multiple perpetrators) in committing a crime. Thus, its two pillars are the multiplicity of perpetrators and the singularity of the crime. Complicity is divided into two types: original complicit (perpetrator and partner) and subordinate complicit (instigator and intervener).
Article 75 has defined the perpetrator as " theone who has carried out acts constituting the elements of a crime or has directly participated in its execution). It should be noted here that this text is likely to address the actual or indirect perpetrator because the article did not differentiate between whether the perpetrator carried out the crime himself or through others). Moreover, Article 76 addressed thetypes ofcomplicities, stating that: (If several individuals committed a felony or misdemeanor, or the felony or misdemeanor consisted of several acts, each one of them who performed one or more acts with the intention of having the felony or misdemeanor take place, are considered complicities. Thus, every one of them is punished by the penalty assigned in the law, as if each one was an independent perpetrator.)

The Jordanian legislator did not define interference in crimes, but included its forms in Article 80/2 for penalties. It stipulates that interference is an act that the complicitin the crime commits and helps to carry out without this constituting an implementing act like in the case of the perpetrator or a complicit. Accordingly, the interference is part of the predicate offense and thus appears at the beginning of the execution of the act which is the physicalaspect of the crime.

As for the instigator, the Jordanian legislator defined this term in Article (1/80) for penalties as: anyone who compels or tries to compel a person to commit a crime by exploiting influence, offering a gift, influencing with threats or deceit, presenting money, or misusing the job's provisions.

Accordingly, the crime of favoritism (Mediation) and nepotism is committed by more than one individual who are as follows: (Al-Rahwan, 2001, p. 39)

Mediator: The person who requests favoritism (Mediation) from the public official.

The one mediated for: the person to whom favoritism (Mediation) is directed, to gain a benefit, i.e. the person of interest or the beneficiary. 
The recipient of favoritism (Mediation) request: the person to whom the favoritism (Mediation) request is submitted, whether he is the decision maker or responsible for implementation, and he must be a public official.

By reviewing the individuals involved in the crime offavoritism (Mediation) and nepotism based on the criminalization text, it is clear that the public official is the main perpetrator, i.e. the original contributor to the crime, being the person intended by the text, the one who accepts a request that is a criminal act, who is aware of his actions and knows the criminal consequences of his acceptance of favoritism (Mediation) yet proceeds further intentionally and without being under any influence.

But those whose characteristics in the crime varies and differs are the mediator and the one mediated for since one of the faults of the text is that these two individuals are not explicitly mentioned and their responsibility is not directly defined, like the public official accepting favoritism (Mediation). Therefore, we believe that our Jordanian legislator must amend the text and define their responsibilities as complicities in the crime, and they must be treated as the original perpetrator ; (the public official) explicitly. Furthermore, these two individuals must be taken seriously, because the crime of favoritism (Mediation) and nepotism is considered a corruption crime that impacts society in all aspects. Therefore, any individual associated with this type of crimes should be considered an original contributor and not a subordinate. Also, considering the acceptance of favoritism (Mediation) by the public official a crime and considering him an original perpetratoraims to prevent him from any act that affects or questions his position and guarantees a good conduct of his duties. If the three individuals (the mediator, the one mediated for, The recipient of favoritism (Mediation) request) were public official, it is better to slow down in adjusting the criminal responsibility and not to consider the mediator and the one mediated for as subordinate contributors but rather original perpetrators. (Hasan, 2010, p . 59)

7. The penalties prescribed for the crime of favoritism (Mediation) and nepotism

Criminal jurisprudence defines penalty as a punishment determined by law for the perpetrator of the crime in the interest of society, and the judge imposes it on whoever is proven responsible for an act considered a crime according to law that intends to inflict harm on a person, his money or esteem (Zain Al-Din, 2009, p .123)

The Jordanian legislatoridentified a criminal penalty for accepting favoritism (Mediation) and nepotism in the text of Article (23) of the Integrity and Anti-Corruption Law No. (13) of 2016 which states that "Without prejudice to any more severe penalty stipulated in any other legislation, a penalty of imprisonment for a period of no less than four months or a fine of not less than five hundred dinars and not more than five thousand dinars or both penalties shall be imposed on whoever commits any of the acts or activities mentioned in Article 16 ) of this law, and in the event of repetition, half of the penalty shall be added to it.

It is notable that this text of the Jordanian legislator is considered unfavorable trend, because it identifies a penalty for all the acts stipulated in Article (16) of the Integrity and Anti-Corruption Law, noting that each crime hasaseparate penalty especially in other criminal legislation, and since the crime offavoritism (Mediation) and nepotism is considered a new crime it was more appropriate to assign a specific penalty for it, similar to the rest of the corruption crimes that is addressed in the aforementioned Article (16).

Article (28 / A) of the Integrity and AntiCorruption Law stipulates that every complicit, interferer or instigator in a corruption crime shall be punished with the penalty prescribed for the perpetrator, and accordingly the legislator assigned a penalty for all those involved in the crime. However, the concern lies in the fact that the mediator and the one mediated for are not held accountable for any crime, especially since the 
excuse relied upon is that the public official was not forced to accept, and no one has authority over him.

\section{Conclusion}

The study addressed the issue of the public official's responsibility in the crime of favoritism (Mediation) and nepotism in accordance with the provisions of Jordanian legislation, and the following conclusionshave been reached:

1- The Jordanian legislator has criminalized the crime of favoritism (Mediation) and nepotism and considered it a corruption crime that is not subject to statute of limitations.

2- The legal texts that address the crime of favoritism (Mediation) and nepotism in the AntiCorruption Law are not clear nor accurate in some cases, such as the use of the phrase (Denying justice or revoking a right), becausesuchphrases are loose, thusinconsistent with the principle of legitimacy. Also, it gives the judge discretionary power in determining their intended meaning.

3 - The crime of favoritism (Mediation) and nepotism presupposes the fulfillment of the presumed element, which is the position of a public official, therefore, acceptance must be madeby him and the criminal responsibility for the crime falls only on him. As for the mediator and the one mediated for, the legislator was not clear in determining their responsibility.

4- There is no specific definition of a public official in the Jordanian legislation.

5- It is considered one of the intentional crimes that are not committed by an unintended mistake, and itssubjective element is represented in the general criminal intent and constructive malice, while the special intent is required in the event that the crime of favoritism (Mediation) and nepotism is related to a crime that requires the availability of special intent such as economic crimes.

6 - The penalty stipulated in the legislation does not constitute the necessary deterrent to eradicate this crime. The legislator did not succeed in merging the punishment of favoritism (Mediation) and nepotism with the rest of the corruption crimes.

7- The manner of addressing the violated rights that resulted from the act of favoritism (Mediation) and nepotism, and the procedure to be followed regarding the one meditated for in case the final judgment condemns the public officialinvolved in the crimehave not been explained.

\section{Recommendations}

1- Amending the criminalization text so that it clarifies the nature of theviolated rights in the crime of favoritism (Mediation) and nepotism, because the phrase "Denying justice or revoking a right" in Jordanian legislation is loose and includes all rights.

2- Adding a provision that explicitly states the criminal responsibility of the mediator and the one meditated for and considers them as original contributors to this crime, whether as perpetrator or complicities in the crime, because had it not been for the request and need for favoritism (Mediation), the crime would not have been committed.

3- Adopting a comprehensive and clear criminal definition for the public official so that some groups do not escape the scope of criminal responsibility.

4- Adding an explicit provision related to all the rights that have been gained by the one meditated for as a result of favoritism (Mediation) and nepotism, and which includes how to address the issue, and how to recover the money obtained through this act of corruption.

5 - Adding an explicit provision related to the link between the crime of favoritism (Mediation) and nepotism and economic crimes, as the general majority of these crimes are based on facilitating the actions of the perpetrator through favoritism (Mediation) and nepotism. Also to aggravate the penalty if they are linked to economic crimes to be considered a felony. 
6- Addressing the attempt of committing the crime of favoritism (Mediation) and nepotism in order to establish the necessary deterrence.

\section{References}

[1] Al-Jbour, Muhammad Odeh (2012). Mediator in the Penal Code, 1st edition, Oman: Wael Publishing House.

[2] Al-Majali, Nitham (2015), Explanation of the Penal Code, General Section, 2nd edition, Amman: Dar Al-Thaqafa for Publishing and Distribution.

[3] Al-Kilani, Farouk. (2011). Corruption Crimes, 1st Edition, Amman: Dar AlRisala Al-Alamiah.

[4] Zainuddin, Bilal Amin. (2009). The phenomenon of administrative corruption in Arab countries and the comparative legislation, 1st edition, Cairo: Dar Al-fikr Al-Jame'i.

[5] Al-Saeed, Kamel (2008). Explanation of crimes harmful to the public interest according to the Penal Code. 1st edition. Amman: Dar Al-Thaqafa for Publishing and Distribution

[6] Saleh, Nael Abdel-Rahman (1992). Embezzlement in Jordanian Law, 1st Edition, Amman: Dar Al-Fikr for Publishing and Distribution.

[7] Al-Raqqad, Meshaal Muhammad. (2012). The Crime of Accepting favoritism (Mediation) in Jordanian Legislation and theProblem of Implementation, Master Thesis, Faculty of Law, Amman Arab University, Amman, Jordan.

[8] Al-Mousawi, Salem Roudhan. (2009). The crime of mediation and recommendation, as a form of corruption, Secular Studies \& Researches Centre, a research published on the website.

[9] Al-Rahwan, Muhammad Hafez. (2001). The Necessity To FightCorruption To Achieve Security And Development, Higher Studies Journal, Fifth Issue.
[10] Mahdi, Saher Abd al-Kadhim. (2010) Administrative corruption, its causes effects, and the most important methods for tackling it, Manpower Management Forum.

[11] Ashraf, Abdel Hamid. (2012). The Role OfMediation In Ending A Criminal Case, 1st Edition, Egypt: Dar Al-Kitab Al Hadith.

[12] Al-Junaidi, Sakhr. (2011). Favoritism (Mediation) And Nepotism are Unjust, Jordan: Zahran Forums

[13] Al-Tamawi, Suleiman. (1982). A Brief on Administrative Law, Cairo: Dar Al Fikr Al Arabi

[14] Mahmoud Hafeth, Mahmoud (1979), Administrative Court, Cairo: Dar AlNahda Al-Arabiya

[15] Al-Jubouri, Saad. (2013). Control of public spending in government contracts, $\mathrm{PhD}$ thesis, unpublished, Tikrit University, Faculty of Law, Iraq.

[16] Masadah, Anwar. (2005). Criminal Responsibility for Economic Crimes, $\mathrm{PhD}$ Thesis, Faculty of Legal Studies, Amman Arab University, Amman.

[17] Hasan, Hussein Mahmoud. (2010). Legal and Institutional Framework for Combating Corruption in Egypt, Worksheet, Regional Seminar on Corruption and Money Laundering Crimes, Sharm El-Sheikh, Egypt.

[18] Al-Saifi, Abdel Fattah. (1998). The State's Right to Punishment, 2nd Edition, Cairo: Dar Al-Nahda Al-Arabiya.

[19] Abu Afifa, Talal. (2012). Explanation of the Penal Code - General Section, 1st Edition, Amman: Dar Al-Thaqafa for Publishing and Distribution. 